\title{
ANALISIS BIAYA BAURAN PROMOSI TERHADAP PENDAPATAN KAMAR DI GRAND MIRAGE RESORT \& THALASSO BALI
}

\author{
Ida Ayu Trisna Wijayanthi ${ }^{1)}$, Ida Bagus Amerta Kusuma ${ }^{2)}$ \\ trisnawijayanthi23@gmail.com
}

STIMI HANDAYANI, Denpasar, Bali-Indonesia

\section{How to cite (in APA style):}

Wijayanthi, I, A, Trisna \& Kusuma, I, B, Amerta (2021). Analisa Biaya Bauran Promosi Terhadap Pendapatan Di Grand Mirage Resort \& Thalasso Bali. Warmadewa Management and Business Joural, 3(1) pp.20-31

\begin{abstract}
Promotion is a strategy used to introduce products or services that are owned in order to increase room revenue in hotels. Grand Mirage Resort \& Thalasso Bali carries out promotional activities by means of advertising, personal selling and sales promotion. However, in reality the cost of the promotional mix and room income do not go hand in hand, so the main point of this research is how the effect of the promotional mix costs on room income at Grand Mirage Resort \& Thalasso Bali and the purpose of this study is to find out how the effect of the promotional mix costs in the form of advertising costs, personal costs selling and sales promotion costs to room revenue at Grand Mirage Resort \& Thalasso Bali. The data analysis technique used in this research uses descriptive quantitative analysis techniques through classical assumption analysis methods, multiple regression analysis, $t$ test, $f$ test and the coefficient of determination. The results of the t test indicate that partially the advertising cost variable has a significant effect on room income. Based on the F test, advertising costs, personal selling costs, and sales promotion costs simultaneously have a significant effect on room revenue. Based on the results of the analysis, the variable advertising costs, personal selling costs, and sales promotion costs, the advertising cost variable that has the most dominant influence on room income at Grand Mirage Resort \& Thalasso Bali.
\end{abstract}

Keywords: Advertising Costs, Personal Selling Costs, Sales Promotion Costs, and Room Revenue.

\begin{abstract}
Abstrak
Promosi merupakan strategi yang digunakan untuk memperkenalkan produk atau jasa yang dimiliki guna meningkatkan pendapatan kamar hotel. Grand Mirage Resort \& Thalasso Bali melaksanakan kegiatan promosi melalui periklanan, personal selling dan promosi penjualan. Namun pada kenyataannya biaya bauran promosi dan pendapatan kamar tidak berjalan seiring, sehingga poin utama dari
\end{abstract}


penelitian ini adalah bagaimana pengaruh biaya bauran promosi terhadap pendapatan kamar di Grand Mirage Resort \& Thalasso Bali dan tujuan dari Penelitian ini bertujuan untuk mengetahui bagaimana pengaruh biaya bauran promosi berupa biaya iklan, biaya pribadi penjualan dan biaya promosi penjualan terhadap pendapatan kamar di Grand Mirage Resort \& Thalasso Bali. Teknik analisis data yang digunakan dalam penelitian ini menggunakan teknik analisis

deskriptif kuantitatif melalui metode analisis asumsi klasik, analisis regresi berganda, uji t, uji f dan koefisien determinasi. Hasil uji t menunjukkan bahwa secara parsial variabel biaya iklan berpengaruh signifikan terhadap pendapatan kamar. Berdasarkan uji F, biaya periklanan, biaya penjualan perorangan, dan biaya promosi penjualan secara simultan berpengaruh signifikan terhadap pendapatan kamar. Berdasarkan hasil analisis, variabel biaya iklan, biaya penjualan pribadi, dan biaya promosi penjualan merupakan variabel biaya iklan yang paling dominan berpengaruh terhadap pendapatan kamar di Grand Mirage Resort \& Thalasso Bali.

Kata Kunci: Biaya Periklanan, Biaya Penjualan Pribadi, Biaya Promosi Penjualan, dan Pendapatan Kamar.

\section{PENDAHULUAN}

Perkembangan industri pariwisata di Bali dapat memberikan berbagai manfaat bagi negara Indonesia, salah satunya adalah mampu menghasilkan devisa yang cukup tinggi bagi negara. Selain itu, industri pariwisata juga dapat memberikan kesejahteraan sosial dan ekonomi apabila dapat dikelola dan dimanfaatkan dengan baik. (Evita et al., 2012) dalam Dampak Perkembangan Pembangunan Sarana Akomodasi Wisata Terhadap Pariwisata Berkelanjutan di Bali mengemukakan "Industri Pariwisata dapat menyerap tenaga kerja dalam jumlah yang besar, mampu meningkatkan pendapatan dan perekonomian serta dapat memberikan kontribusi yang besar pada suatu negara. Hal inilah yang mendorong banyak negara tertarik untuk mengembangkan pariwisata sebagai salah satu sektor pembangunan, terutama bagi negara yang sedang berkembang termasuk Indonesia

Semakin marak berkembangnya hotel - hotel baru dalam berbagai kelas dan klasifikasinya, para pengusaha akomodasi dituntut untuk dapat bersaing dalam meningkatkan pendapatan kamar yang merupakan kontribusi terbesar bagi industri perhotelan. Tinggi rendahnya pendapatan hotel sangat dipengaruhi oleh pengelolaan dan pemanfaatan modal, fasilitas yang tersedia, sumber daya manusia dan juga promosi yang dilakukan. Begitu pula dengan Grand Mirage Resort \& 
Thalasso Bali, yang selalu berusaha untuk meningkatkan tingkat hunian kamarnya dari tahun ke tahun.

Departemen pemasaran di Grand Mirage Resort \& Thalasso Bali sangat memperhatikan sistem pemasaran dan promosi penjualan secara efektif terhadap produk yang dimiliki seperti fasilitas kamar yang ditawarkan kepada pangsa pasar yang diinginkan agar tidak direbut oleh para pesaing lain yang memiliki produk yang sama. Bauran promosi yang saat ini lebih sering digunakan oleh Grand Mirage Resort \& Thalasso Bali yaitu advertising, personal selling dan sales promotion. Bauran promosi tersebut tentu berdampak pada biaya yang tidak sedikit dikeluarkan oleh hotel untuk memperoleh pendapatan yang telah ditetapkan.

Mengingat pentingnya kegiatan bauran promosi dalam usaha memperoleh pendapatan yang besar, maka diperlukan suatu biaya dalam pelaksanaan kegiatan promosi tersebut. Sejumlah biaya bauran promosi yang dikeluarkan yaitu dalam bentuk biaya advertising, biaya personal selling, biaya sales promotion, diharapkan mampu meningkatkan volume penjualan dan pendapatan kamar di Grand Mirage Resort \& Thalasso Bali. Berdasarkan latar belakang masalah tersebut, maka yang menjadi tujuan dari penelitian adalah untuk mengetahui bagaimana pengaruh baik secara parsial maupun simultan antara pengaruh biaya promosi dalam hal ini biaya advertising, biaya personal selling, biaya sales promotion dengan pendapatan kamar di Grand Mirage Resort \& Thalasso Bali, sehingga hasil penelitan diharapkan mampu memberikan gambaran bagi pelaku usaha serupa mengenai pengaruh biaya biaya promosi tersebut terhadap penjualan.

\section{TELAAH LITERATUR DAN KAJIAN PUSTAKA}

\section{A. Advertising (Periklanan)}

Periklanan adalah pendekatan yang menggunakan media komunikasi untuk menyampaikan informasi kepada khalayak ramai dalam satu waktu dengan membaca atau melihat yang diharapkan para calon konsumen akan tertarik untuk membeli. Oleh karena itu, maka dalam memilih media iklan harus diperhatikan pasar sasaran yang dituju. Menurut Handayani (2010:175), periklanan adalah : Promosi yang dituangkan dalam bentuk presentasi barang ataupun jasa melalui 
sponsor atau media tertentu. Media tertentu yang dimaksud adalah seperti iklan di surat kabar, iklan TV, surat khusus, packaging, insert, majalah, internet, poster, billboards,audio visual materials, dan lain sebagainya. Sementara Itu Kasali (2007:9) periklanan adalah "pesan yang menawarkan suatu produk yang ditunjukkan kepada masyarakat lewat suatu media”. Sedangkan Morissan (2010:18) periklanan adalah "suatu instrument promosi yang penting, terutama bagi perusahaan yang memproduksi barang atau jasanya untuk masyarakat". Dari ketiga definisi di atas dapat di katakana advertising merupakan alat untuk mempromosikan produknya baik yang baru maupun lama, guna mendapatkan daya tarik bagi calon konsumennya.

\section{B. Personal Selling (Penjualan Pribadi)}

Personal selling adalah komunikasi langsung (tatap muka) antara penjual dan calon pelanggan untuk memperkenalkan suatu produk kepada calon pelanggan dan membentuk pemahaman pelanggan terhadap produk sehingga mereka akan mencoba membelinya. Menurut Handayani (2010:174) menyatakan penjualan pribadi adalah : Kegiatan pendekatan interaksi empat mata (face to face) dengan satu atau lebih target yang bertujuan menghasilkan sebuah transaksi pembelian. Beberapa kegiatan personal selling ini meliputi presentasi penjualan program, incentive, sales meeting, dan pemberian sample. Sementara itu Tjiptono (2008:285), menyatakan personal selling adalah : Komunikasi langsung (tatap muka) antara penjual dan calon pelanggan untuk memperkenalkan suatu produk kepada calon pelanggan dan membetnuk pemahaman terhadap produk sehingga mereka kemudian akan mencoba membelinya.

\section{Sales Promotion (Promosi Penjualan)}

Sales Promotion adalah cara yang digunakan oleh penjual dalam memasarkan atau menginformasikan, membujuk atau mempengaruhi calon pembelinya. Menurut Handayani (2010:174), menyatakan bahwa promosi penjualan adalah : Merupakan insentif jangka pendek untuk mendorong suatu produk ataupun jasa, promosi penjualan ini dapat dilakukan melalui contents, 
games, lotteries, premium, hadiah, sampling, trade shows, diskon, entertainment, trade promotions dan kupon berhadiah. Sementara itu Oka A. Yoeti (2013:45) menyatakan bahwa sales promotion adalah : Salah satu cara yang penting melakukan persaingan dengan tidak didasarkan kepada harga. Suatu usaha sales promotion, jika dilaksanakan dengan baik, akan dapat mempengaruhi konsumen mengenai dimana dan bagaimana konsumen mempergunakan pendapatannya (income). Sedangkan Kotler (2005:298) sales promotion adalah "berbagai kumpulan alat - alat insentif, yang sebagian besar jangka pendek, yang dirancang untuk merangsang pembelian produk atau jasa tertentu dengan lebih cepat dan lebih besar oleh konsumen atau pedagang”. Dari ketiga definisi di atas dapat di katakan sales promotion (promosi penjualan) merupakan cara untuk menarik perhatian calon konsumen untuk mau mencoba produk yang dijual.

\section{Pengertian Pendapatan Kamar}

Pendapatan kamar adalah hasil yang diperoleh dari penjualan kamar. Sedangkan penjualan kamar merupakan sumber pendapatan terbesar yang dihasilkan oleh hotel disamping pendapatan dari penjualan fasilitas lainnya, seperti makanan, minuman, dan pelayanan yang diberikan selama tamu menginap. Menurut Endar Sugiarto dalam Sutisna (2008:79) pendapatan kamar adalah "jumlah total yang diperoleh dan penjualan kamar dalam satu malam, dengan jenis cara pembayaran yang bermacam". Sementara itu menurut Wiyasha (2010:22), mengemukaan bahwa pendapatan kamar "memberikan kontribusi pendatang terbesar, berkisar antara $60-70 \%$ dari seluruh pendapatan hotel, diikuti oleh bagian makanan 25 - 35\%, dan minuman dengan kisaran kontribusi $10-15 \%$ dart total pendapatan hotel”. Dari kedua definisi diatas dapat di katakan pendapatan kamar merupakan pendapatan dari hasil penjualan kamar yang digunakan atau disewa oleh tamu yang menginap di hotel dengan jenis cara pembayaran yang bermacam.

\section{E. Hipotesis}

Berdasarkan tujuan penelitian, tinjauan teoritis dan penelitian terdahulu yang dikemukakan, maka hipotesis dirumuskan sebagai berikut : 
1. H1: Biaya advertising berpengaruh positif dan signifikan terhadap pendapatan kamar di Grand Mirage Resort \& Thalasso Bali.

2. H2: Biaya personal selling berpengaruh positif dan signifikan terhadap pendapatan kamar di Grand Mirage Resort \& Thalasso Bali.

3. H3: Biaya sales promotion berpengaruh positif dan signifikan terhadap pendapatan kamar di Grand Mirage Resort \& Thalasso Bali.

4. H4: Biaya advertising, biaya personal selling, dan biaya sales promotion secara bersamaan berpengaruh positif dan signifikan terhadap pendapatan kamar di Grand Mirage Resort \& Thalasso Bali

III. METODE PENELITIAN

Gambar III.1 Kerangka Pemikiran

Pengaruh Biaya Bauran Promosi Terhadap Pendapatan Kamar di Grand Mirage Resort \& Thalasso Bali

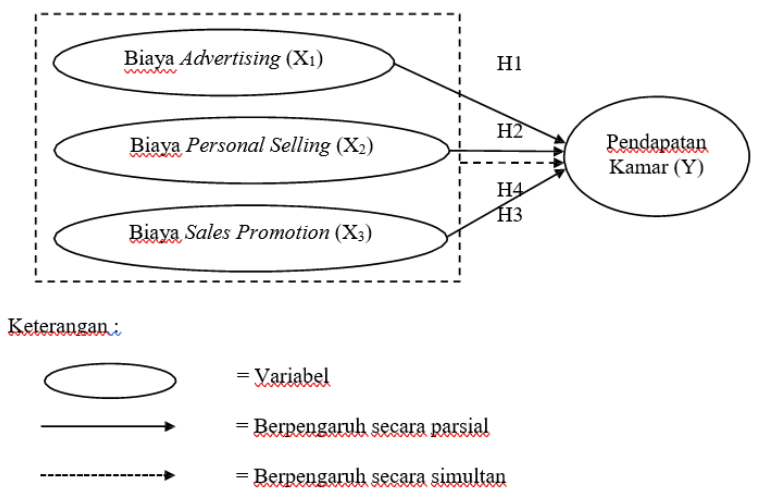

Sumber : Teori dan penelitian terdahulu yang diolah,

Dalam penelitian ini, obyek penelitian difokuskan pada pengaruh biaya promosi yaitu Biaya advertising, Biaya personal selling, dan Biaya sales promotion terhadap pendapatan kamar di Grand Mirage Resort \& Thalasso Bali. Pada penelitian ini teknik analisis data menggunakan analisis kualitatif dengan menggunakan teknis analisis data yaitu menggunakan analisis Regresi Berganda dengan pengolahan data menggunakan IBM SPSS Statistics 20 for Windows. Adapun tahapan-tahapan analisis adalah sebagai berikut: Uji Asumsi Klasik, 
Analisis Regresi Linier Berganda, Uji Hipotesis Uji $t$ (parsial), Uji $F$ (Simultan) dan Uji Determinasi $\left(\mathrm{R}^{2}\right)$.

\section{HASIL PENELITIAN DAN PEMBAHASAN}

Uji asumsi klasik menghasilkan sebagai berikut, adapun hasil uji normalitas data menjelaskan bahwa sebaran titik- titik residual berada disekitar garis normal. Dengan demikian dapat disimpulkan bahwa regresi telah memenuhi persyaratan normalitas (distribusi normal), dimana data yang baik dan layak digunakan adalah data yang memiliki distribusi normal. Hasil uji multikolinearitas hasil pengujian tolerance menunjukkan semua variabel bebas memiliki nilai tolerance lebih besar dari $0,10(10 \%)$, yaitu variabel biaya advertising $0.922>0.10$, variabel biaya personal selling $0.908>0.10$, dan variabel biaya sales promotion $0.951>0.10$. Hasil perhitungan Variance Iflaction Factor (VIF) juga menunjukkan bahwa semua variabel bebas memiliki nilai VIF lebih kecil dari 10, yaitu biaya advertising $1.084<10$, biaya personal selling $1.101<10$, dan biaya sales promotion $1.052<$ 10. Oleh karena itu dapat disimpulkan tidak ada multikolinearitas antara variabel dalam model regresi. Hasil Uji heteroskedastisitas terlihat bahwa sebaran titik tidak membentuk suatu pola atau alur tertentu, sehingga dapat disimpulkan tidak terjadi heteroskedastisitas atau dengan kata lain terbebas dari asumsi klasik heteroskedastisitas, dimana model regresi yang baik adalah regresi yang bebas dari heteroskedastisitas. Hasil Uji autokorelasi ditemukan Durbin - Watson test =1,552 maka, dapat dikatakan bahwa data yang diteliti tidak terjadi autokorelasi karena nilai Durbin - Watson terletak pada kisaran klasifikasi Durbin - Watson 1,55 - 2,46. Dimana model regresi yang baik adalah model regresi yang bebas dari autokorelasi.

Adapun hasil uji analisis regresi linier berganda setelah data diolah menggunakan SPSS versi 24 dengan menganalisa biaya advertising, biaya personal selling, dan biaya sales promotion didapatkan hasil sebagai berikut : 
Tabel 4.1 Hasil Uji Analisis Regresi Linier Berganda

\begin{tabular}{|c|c|c|c|c|c|c|}
\hline \multicolumn{7}{|c|}{ Coefficients $^{\mathrm{a}}$} \\
\hline & & \multicolumn{2}{|c|}{ Unstandardized Coefficients } & \multirow{2}{*}{\begin{tabular}{|c|}
$\begin{array}{r}\text { Standardized } \\
\text { Coefficients }\end{array}$ \\
Beta \\
\end{tabular}} & \multirow{2}{*}{$\mathbf{t}$} & \multirow{2}{*}{ Sig. } \\
\hline \multicolumn{2}{|c|}{ Model } & B & Std. Error & & & \\
\hline \multirow[t]{4}{*}{1} & (Constant) & $\begin{array}{r}2779371308 . \\
000\end{array}$ & $\begin{array}{r}2268164449 \\
000 \\
\end{array}$ & & 1.225 & .229 \\
\hline & Advertising & 18.850 & 6.752 & .451 & 2.792 & .009 \\
\hline & $\begin{array}{l}\text { Personal } \\
\text { Selling }\end{array}$ & .382 & 9.156 & .007 & 2.042 & .967 \\
\hline & $\begin{array}{l}\text { Sales } \\
\text { Promotion }\end{array}$ & 6.308 & 10.346 & .097 & 2.610 & .546 \\
\hline
\end{tabular}

Sumber: data diolah

Model regresi tersebut menunjukkan arah hubungan masing - masing variabel bebas terhadap variabel terikat. Persamaan regresi tersebut dapat dijelaskan sebagai berikut :

a. Bila seluruh variabel bebas yaitu biaya advertising, biaya personal selling, dan biaya sales promotion diasumsikan konstan pada nilai 0 (nol), maka pendapatan kamar akan sebesar 2.779.371.308,000.

b. Biaya advertising terhadap pendapatan kamar, nilai koefisien biaya advertising (X1) sebesar 18.850 dengan catatan variabel yang lain konstan hal ini berarti bahwa setiap kenaikan biaya advertising satu satuan, maka pendapatan kamar (Y) akan meningkat sebesar 18.850. Tanda positif (+) menunjukkan bahwa variabel biaya advertising (X1) memiliki pengaruh positif terhadap pendapatan kamar.

c. Biaya personal selling terhadap pendapatan kamar, nilai koefisien biaya personal selling (X2) sebesar 0.382 hal ini menunjukkan bahwa setiap kenaikan biaya personal selling satu satuan, maka pendapatan kamar (Y) akan meningkat sebesar 0.382 . Tanda positif $(+)$ menunjukkan bahwa variabel biaya personal selling (X2) memiliki pengaruh positif dan tidak signifikan terhadap pendapatan kamar. 
d. Biaya sales promotion terhadap pendapatan kamar, nilai koefisien biaya sales promotion (X3) sebesar 6.308 hal ini menunjukkan bahwa setiap kenaikan biaya sales promotion satu satuan, maka pendapatan kamar (Y) akan meningkat sebesar 6.308. Tanda positif $(+)$ menunjukkan bahwa variabel biaya sales promotion (X3) memiliki pengaruh positif dan tidak signifikan terhadap pendapatan kamar.

Berdasarkan table 4.1 dapat diketahui hasil analisis Uji t secara parsial yaitu sebagai berikut

a. Hasil perhitungan pada variable biaya advertising menunjukkan bahwa thitung dan ttabel yaitu 2,792 > 2,032, maka biaya advertising memiliki hubungan atau pengaruh yang signifikan terhadap pendapatan kamar di Grand Mirage Resort \& Thalasso Bali sehingga H1 diterima. Hal ini sejalan dengan beberapa hasil penelitian, hasil penelitian dari (Atmojo, 2011) mengenai "Pengaruh Biaya Bauran Promosi Dalam Meningkatkan Tingkat Okupansi Hotel Novotel Balikpapan" yang menyebutkan secara parsial terdapat pengaruh postif dan signifikan terhadap pendapatan kamar.

b. Hasil perhitungan pada variable biaya personal selling menunjukkan bahwa thitung dan ttabel yaitu 2,042>2,032, maka biaya personal selling memiliki hubungan atau pengaruh yang signifikan terhadap pendapatan kamar di Grand Mirage Resort \& Thalasso Bali sehingga H2 diterima. Hal ini sejalan dengan hasil penelitian (Mahendra, 2017) mengenai "Pengaruh Biaya Personal Selling, Biaya Advertising, dan Biaya Sales Promotion Terhadap Pendapatan Kamar di The Laguna, A Luxury Collection Resort \& Spa Nusa Dua Bali” yang menyebutkan secara parsial dan simultan terdapat pengaruh postif dan signifikan terhadap pendapatan kamar.

c. Hasil perhitungan pada variable biaya sales promotion menunjukkan bahwa thitung dan ttabel yaitu 2,610>2,032, maka biaya sales promotion memiliki hubungan atau pengaruh yang signifikan terhadap pendapatan kamar di Grand Mirage Resort \& Thalasso Bali sehingga H3 diterima. Hasil penelitian ini juga sejalan dengan hasil penelitian yang dilakukan oleh (Armana et al., 2015) 
mengenai “Analisis Pengaruh Biaya Periklanan, Biaya Penjualan Pribadi, dan Biaya Promosi Penjualan Terhadap Pendapatan Kamar Hotel di Singaraja”. Hasil dari penelitian tersebut menunjukkan bahwa berdasarkan uji $t$, secara parsial biaya sales promotion berpengaruh signifikan terhadap pendapatan kamar hotel di Singaraja. Sedangkan uji F, secara simultan biaya periklanan, biaya penjualan pribadi, dan biaya promosi penjualan berpengaruh signifikan terhadap pendapatan kamar hotel di Singaraja

Sedangkan berdasarkan hasil perhitungan uji $\mathrm{F}$ menunjukkan bahwa Fhitung $\geq$ Ftabel, yaitu 3,159 $\geq 2,90$, maka Ho ditolak dan Ha diterima yang berarti terdapat pengaruh yang signifikan antara biaya advertising (X1), biaya personal selling (X2), dan biaya sales promotion (X3) secara simultan terhadap pendapatan kamar (Y) di Grand Mirage Resort \& Thalasso Bali. Hasil perhitungan analisis koefisien determinasi memberikan informasi bahwa biaya advertising, biaya personal selling, dan biaya sales promotion berpengaruh sebesar $22,8 \%$ terhadap pendapatan kamar di Grand Mirage Resort \& Thalasso Bali yang dapat diartikan bahwa biaya advertising, biaya personal selling, dan biaya sales promotion memberikan pengaruh atau kontribusi yang rendah atau lemah terhadap pendapatan kamar di Grand Mirage Resort \& Thalasso Bali, sedangkan sisanya sebesar 77,2\% dipengaruhi oleh faktor lain yang tidak diamati dalam penelitian ini.

\section{SIMPULAN}

Berdasarkan hasil analisis yang telah dilakukan, maka diperoleh beberapa simpulan tentang pengaruh biaya bauran promosi terhadap pendapatan kamar di Grand Mirage Resort \& Thalasso Bali sebagai berikut : Hasil analisis biaya advertising, biaya personal selling dan biaya sales promotion secara parsial menunjukkan bahwa dalam uji t semua variabel bebas memiliki pengaruh yang signifikan terhadap pendapatan kamar di Grand Mirage Resort \& Thalasso Bali. Secara simultan biaya bauran promosi yang terdiri dari biaya advertising, biaya personal selling, dan biaya sales promotion memberikan pengaruh pengaruh yang signifikan. Sedangkan perhitungan analisis koefisien determinasi memberikan informasi bahwa biaya advertising, biaya personal selling, dan biaya sales 
promotion berpengaruh atau berkontribusi sebesar 22,8\% yang artinya dikategorikan pada tingkat rendah atau lemah terhadap pendapatan kamar di Grand Mirage Resort \& Thalasso Bali, sedangkan sisanya sebesar 77,2\% dipengaruhi oleh faktor lain yang tidak diamati dalam penelitian ini.

Ketrebatasan penelitian ini adalah hanya meneliti tiga komponen dari bauran promosi serta hanya pada satu tempat saja yaitu pada Grand Mirage Resort $\&$ Thalasso Bali. Selanjutnya disarankan untuk diadakan penelitian serupa dengan penambahan variabel bebas yaitu menggunakan semua komponen bauran promosi dan disertakan pembanding dibeberapa lokasi penelitian yang berbeda.

\section{DAFTAR PUSTAKA}

A.M, Morissan. 2010. Periklanan Komunikasi Pemasaran Terpadu. Jakarta: Kencana.

Armana, Adi. (2013). Analisis Pengaruh Biaya Periklanan, Biaya Personal Selling, dan Biaya Promosi Penjualan Terhadap Pendapatan Kamar Hotel Damai di Singaraja. Bali: Universitas Pendidikan Ganesha Singaraja, Indonesia.

Atmojo, A.Rinto Dwi. (2011). Pengaruh Bauran Promosi Dalam Meningkatkan Tingkat Okupansi Hotel Novotel Balikpapan. Balikpapan: Politeknik Negeri Samarinda.

Evita, Rossi, dkk. 2012. Dampak Perkembangan Pembangunan Sarana Akomodasi Wisata Terhadap Pariwisata Berkelanjutan Di Bali. Bali: Universitas Udayana.

Handayani, Desy \& dkk. 2010. The Official MIM Academy Coursebook Brand.Operation. Jakarta: Esensi Erlangga Group.

Kasali, Rhenald. 2007. Membidik Pasar Indonesia Segmentasi Targeting Positioning. Jakarta: PT Gramedia Pustaka Utama.

Kotler, Philip. 2005. Manajemen Pemasaran, Jilid I dan II. Jakarta: PT. Indeks.

Mahendra, Eka. (2017). Pengaruh Biaya Personal Selling, Biaya Advertising, dan Biaya Sales Promotion Terhadap Pendapatan Kamar di The Laguna, A Luxur Collection Resort \& Spa, Nusa Dua, Bali. Bali : Sekolah Tinggi Pariwisata Bali.

Suartawan, Adi. (2018). Pengaruh Personal Selling Terhadap Pendapatan Kamar di Hotel Sofitel Bali Nusa Dua Beach Resort. Bali: Sekolah Tinggi Pariwisata Bali.

Sutisna. 2008. Perilaku Konsumen dan Komunikasi Pemasaran. Bandung: PT Remaja Rosdakarya.

Tjiptono, Fandy. 2008. Strategi Pemasaran Edisi 3. Yogyakarta: Andi. 
Udiatmika, Wira. (2013). Pengaruh Biaya Bauran Promosi Terhadap Pendapatan Kamar di Hotel Aditya Beach Resort Lovina. Bali: Universitas Panji Sakti Singaraja.

Wiyasha, IBM. 2010. Akuntasi Perhotelan-Penerapan Uniform System Account for the Lodging Indistry. Yogyakarta: Andi Offset.

Yoeti, Oka A. 2013. Pemasaran Pariwisata, Edisi Revisi. Bandung: CV Angkasa. 